\title{
Misattributed blame? Attitudes toward globalization in the age of automation
}

\author{
Nicole $\mathrm{Wu}^{1,2}$ \\ ${ }^{1}$ University of Toronto, Toronto, ON, Canada and ${ }^{2}$ University of Michigan, Ann Arbor, MI, USA \\ Corresponding author. Email: nicolek.wu@utoronto.ca
}

(Received 23 June 2020; revised 30 November 2020; accepted 14 February 2021; first published online 15 July 2021)

\begin{abstract}
Many, especially low-skilled workers, blame globalization for their economic woes. Robots and machines, which have led to job market polarization, rising income inequality, and labor displacement, are often viewed much more forgivingly. This paper argues that citizens have a tendency to misattribute blame for economic dislocations toward immigrants and workers abroad, while discounting the effects of technology. Using the 2016 American National Elections Studies, a nationally representative survey, I show that workers facing higher risks of automation are more likely to oppose free trade agreements and favor immigration restrictions, even controlling for standard explanations for these attitudes. Although pocket-book concerns do influence attitudes toward globalization, this study calls into question the standard assumption that individuals understand and can correctly identify the sources of their economic anxieties. Accelerated automation may have intensified attempts to resist globalization.
\end{abstract}

Keywords: International political economy; public opinion

\section{Introduction}

From the United States to Europe and beyond, populist leaders are enjoying a resurgence propelled by widespread resentment toward globalization. The United Kingdom's decision to withdraw from the European Union is widely viewed as a rejection of integration. Marine Le Pen took National Front from the fringes of French politics to the forefront by condemning immigration and criticizing international institutions. Globalization was vehemently attacked by the left and right during the 2016 American presidential election. Populists blame globalization for causing underemployment, wage stagnation, growing inequality, and the disappearance of well-paid factory jobs.

Although globalization has important distributional effects, neither trade, immigration, nor offshoring explain the preponderance of affected workers' plight. The existing scholarship highlights technology's link to many of the structural economic changes witnessed in advanced industrialized countries (Bekman et al., 1998; Acemoglu and Restrepo, 2018, 2020). Acemoglu and Restrepo (2020), for example, find large and robust negative effects of robots on employment and wages across commuting zones. Technological change is also linked to job polarization and increasing income inequality, hurting especially those in the middle of the education and earnings distribution (Goos and Manning, 2007). Although automation had mostly threatened workers who perform routine and repetitive tasks in the past, rapid developments in robotics and artificial intelligence now threaten even non-routine jobs. Frey and Osborne (2017) estimate that 47 percent of American jobs are at high risks of automation.

(C) The Author(s), 2021. Published by Cambridge University Press on behalf of the European Political Science Association. This is an Open Access article, distributed under the terms of the Creative Commons Attribution licence (http://creativecommons.org/licenses/by/4.0/), which permits unrestricted re-use, distribution, and reproduction in any medium, provided the original work is properly cited. 
Globalization receives outsized attention in political discussions, while automation is often ignored. This paper argues that the threat of automation intensifies efforts to restrict globalization. Individuals tend to displace blame for economic dislocations toward outgroups, immigrants and workers abroad. Using the American National Elections Studies (ANES), a nationally representative survey, I show that American workers facing higher risk of automation are significantly more likely to oppose free trade agreements and immigration, even when controlling for standard explanations for these attitudes. These findings suggest that workers are misattributing blame for harmful changes in labor markets toward immigrants and foreign workers.

This argument relates to two traditional approaches to the study of mass attitudes toward globalization. The first posits that individual preferences should reflect economic self-interest. In studying attitudes toward trade, analysts typically derive predictions about individuals' material interests based on the Ricardo-Viner or Stolper-Samuelson model (Scheve et al., 2001). In doing so, they assume that citizens understand and can accurately identify the sources of their financial stressors or fortunes. The second approach demonstrates that citizens are either disinterested or unable to engage in such reasoning. These researchers instead emphasize non-economic influence on preferences. Opponents of globalization are not necessarily economic losers. Economic ignorance, ethnocentrism, political framing, and other symbolic attitudes, rather than pocketbook concerns, determine attitudes toward globalization (Mansfield and Mutz, 2013; Goldstein and Peters, 2014; Rho and Tomz, 2017).

In this paper, I contend that grievances against globalization have economic origins, but economic losers often misattribute blame for their anxieties, and consequently, demand policies that poorly advance their interests. Although automation threat is associated with lower levels of job security, citizens do not always make the correct inference about the source of such anxiety. This paper uses the United States as an illustrative case where conditions are ripe for blame displacement, but the country is not unique. People in advanced economies tend to overestimate the extent of globalization (e.g., size of immigrant population) (Alba et al., 2005; Semyonov et al., 2008) and underestimate personal risks of automation. Many also see foreigners and robots through different lenses. Although many believe that technology will raise the competitiveness of their firms and facilitate human progress, outgroups are often viewed in zero-sum terms. Populist leaders tap into this sentiment by attributing economic anxieties to the competition from immigrants and workers abroad. Outside of the USA, globalization has also become a salient issue and is openly attacked by politicians across much of Europe (Mader et al., 2020). According to theories of motivated reasoning, this vilification of foreigners is likely to be a particularly convincing narrative for those who are economically threatened as it validates their preexisting beliefs about zero-sum competition with outgroups, leading to higher rates of blame misattribution. Psychological research also demonstrates that blaming outgroup helps individuals restore a sense of personal control.

This misattribution of blame may lead to poor policy outcomes. If trade and immigration have key positive benefits for consumers and the overall growth of the economy, responding to technological change with closed borders may harm constituencies that derive key benefits from imported goods and immigrant communities. Protectionism may even hurt those who demand these policies in the first place if they are misidentifying the source of their economic problems. In addition, the overwhelming focus on tariffs and border controls as means to reduce inequality and prop up the middle class takes public attention away from other pertinent issues such as job automation. Technology destroys jobs, but it may also create new ones. It is important for individuals to be aware of the challenges and opportunities related to technology, and to discuss how governments may facilitate the development of skills that complement technological change and formulate appropriate adjustment policies for displaced workers. Compensating losers of globalization has also long been believed to weaken protectionist impulses (Hays et al., 2005; Walter, 2010; Schaffer et al., 2016). Finally, the misplacement of hostility has had important political ramifications on the state of globalization. Populist leaders in the United States, 
United Kingdom, and elsewhere have found electoral successes by framing globalization as the main cause of structural economic changes and promising a retreat from the global market. The fracturing of international political and economic unions and agreements are often economically detrimental and difficult to reverse.

\section{Structural changes in the American economy}

\subsection{Globalization and secular economic trends}

In developed economies, secular economic trends-deindustrialization, wage stagnation, and growing income inequality - coincided with immense increases in trade, offshoring, and immigration. The concurrence of growing global integration and structural economic change has led many to believe that reversing globalization will undo these changes. However, the scholarship shows that trade only accounts for a minor share of layoffs and other labor market shocks (Freeman, 1995; Di Tella and Rodrik, 2020). Most workers in advanced economies are employed in the service sector and are largely immune to pressures of import competition. The manufacturing sector, which experienced higher incidences of trade-related layoffs, employs less than 10 percent of Americans. Although recent study on the "China shock" shows the negative effects of Chinese imports on jobs and wages, scholars find that employment gains due to export expansion roughly offset these losses (Feenstra et al., 2019). Overall, trade barriers may protect only a modest number of workers while hurting many others: the export sector (Weymouth, 2017) and consumers who enjoy welfare gains due to lower prices.

Populists also point the finger at immigrants for displacing native workers and depressing their wages, but research in economics provides little support for their claims. Using a natural experiment, Card (1990) shows that the sudden influx of Cuban migrants had virtually no effect on wages or unemployment rates for low-skilled workers in Miami. ${ }^{1}$ Peri and Sparber (2009) further argue that immigrants boost productivity and wages in the long run. Native workers tend to transition into communication- and cognitive-intensive jobs as immigrants take lower-skill and manual jobs. Immigrants also contribute more in taxes than the benefits they receive. Populists' economic case against immigrants is largely unsupported. Although protectionists have not gone so far as to advocate capital controls, they shame multinational firms for moving production abroad and call for onshoring. However, offshore workers are not good substitutes for native workers due to different task specializations (Ottaviano et al., 2013). Offshore workers are often assigned tasks of lower complexity and this leads to task-upgrading among natives. In addition, only a small number of workers lost their jobs due to offshoring. According to the Bureau of Labor Statistics (BLS), movement-of-work accounted for just 3 percent of layoffs. ${ }^{2}$ Capital flows are also a two-way street, but the BLS does not collect data on jobs created by foreign firms in the United States.

\subsection{Technological and automation threat}

Although globalization has no doubt created winners and losers, neither international trade, immigration, nor offshoring explain the preponderance of the latter's plight. The literature on structural economic change emphasizes technology as a more important source of economic disruption. Since the 1980s, a marked increase in labor productivity due to technological upgrades

\footnotetext{
${ }^{1}$ Borjas (1995) reanalyzes the data and finds that there was a decrease in low-skill wages between 1979 and 1985. Peri and Yasenov (2019) find that Borjas arrived at his conclusions by using a small subsample of high school dropouts (fewer than 25).

${ }^{2}$ Note that this figure may overstate the effect of offshoring as it includes both out-of-country and domestic relocations. This figure was from 2012, the last year the statistic was reported.
} 


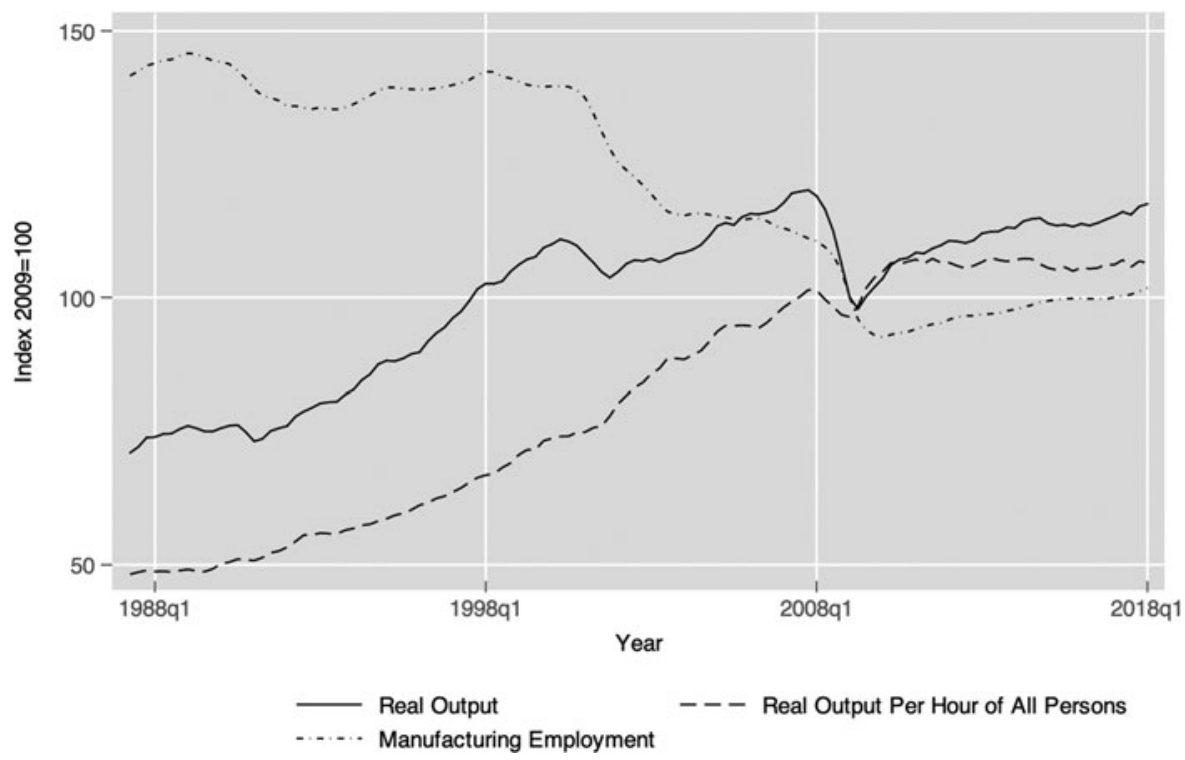

Figure 1. Manufacturing output and employment (1987-2018).

Note: Data from the Federal Reserve Bank of St. Louis Economic Research Division.

enabled real-manufacturing output to almost double despite a 30 percent decrease in employment (Figure 1). ${ }^{3}$

Although declining manufacturing employment was at the forefront of issues during the 2016 US presidential election, technology has played (and will likely play) a more important role in reshaping labor market outcomes than globalization, whether in the primary, manufacturing, or service sectors. Acemoglu and Restrepo (2020) find large and robust negative effects of robots on employment and wages. The introduction of one new robot decreases employment by 5.6 workers, and an additional industrial robot per thousand workers reduces wages by 0.5 percent. These labor market effects most affected individuals with less than college education and workers in routine occupations. These findings are consistent with extant research on technological change which shows that post-1980 mechanization has been skill-biased and routine-biased, privileging skilled over unskilled workers, and non-routine over routine jobs (Bekman et al., 1998; Acemoglu and Restrepo, 2020). Importantly and perhaps surprisingly, technology has not produced offsetting employment gains in any occupation or education groups (Acemoglu and Restrepo, 2020).

Automation had thus far most threatened workers who perform routine tasks as machines have comparative advantage in performing well-defined tasks. Routine jobs can be cognitive or manual. Routine manual work tends to be blue collar jobs, such as food batchmakers and plant operators; whereas routine cognitive jobs generally require some level of precision, training, or education, examples include bookkeepers and travel agents. These jobs tend to be in the middle of the wage distribution (Goos and Manning, 2007). Automation has yet to pose widespread challenges to those in non-routine cognitive and manual jobs that occupy the opposite ends of the skill- and wage-spectrum, although this is set to change. The former includes well-paid managerial, professional, and technical workers, including doctors and software programmers, whereas the latter are generally low-paying service sector jobs such as cleaners and servers. Taken together,

\footnotetext{
${ }^{3}$ Between 2000 and 2010, Hicks and Devaraj (2015) estimate that over 85 percent of job losses in manufacturing were the result of productivity increases due to the adoption of new technology, and only 13 percent were lost to trade. Had the USA maintained its level of productivity in 2000, it would require an extra 8.8 million more workers than it actually employed in 2010 to produce the 2010-level output.
} 


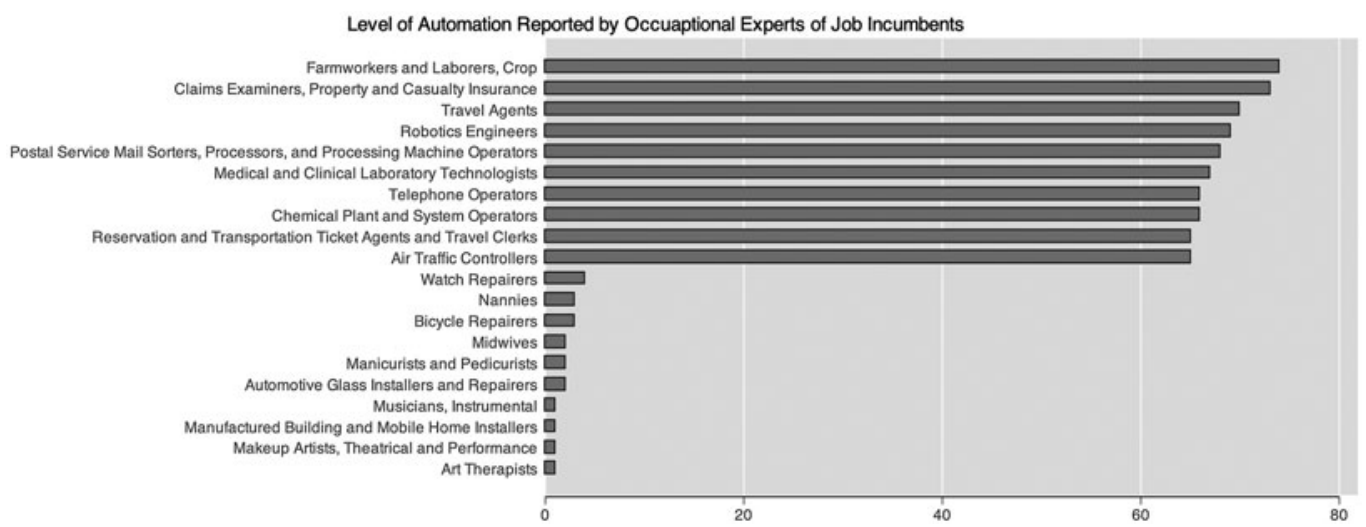

Figure 2. The most and least automated jobs.

Note: Drawn from a survey sponsored by the Department of Labor. It asks a representative sample of job incumbents or occupation experts the extent of automation of their jobs.

technological change has led to the hollowing out of the middle and is linked to growing inequality. Figure 2 shows the most and least automated jobs in the early 2010s as reported by occupational experts and job incumbents.

Advances in artificial intelligence and robotics are putting more jobs at risk. Frey and Osborne (2017) estimate that 47 percent of American jobs can be replaced by machines due to these new developments. Different from the past, computerization is no longer confined to routine tasks. Machine learning, including data mining, machine vision, and neural networks allow even cognitive tasks to be automated. Occupations which had not been computerized could face a high risk of automation in the future as technology becomes more sophisticated and cheaper. ${ }^{4}$

Technology may in the long run create new jobs, ${ }^{5}$ but workers displaced by technology may not be qualified for the new jobs that are created. Many former workers in routine occupations shifted into low-wage service jobs or dropped out of the labor force altogether. Oftentimes, they had to exit highly unionized sectors and settle for precarious non-unionized jobs and were, in many cases, deprived of medical benefits and pension rights. Laborers in demand in the future would tend to be those who are technically skilled or possess a comparative advantage over robots (e.g., good interpersonal skills and creativity).

\section{Blame misattribution: scapegoating globalization}

Although technology has disrupted workers' livelihoods in the past and is poised to do so at a faster pace and larger scale in the near future, globalization is disproportionately blamed in politics. Populist leaders and their supporters believe retreating from the global economy will address the negative changes in the labor market of the last few decades.

\subsection{Politically motivated framing by elites}

The narrative that foreign imports and offshoring are killing the manufacturing sector became the dominant frame to understand job insecurity across much of the developed world. Campaign

\footnotetext{
${ }^{4}$ Automation is conceivably imminent in several occupations: Diagnostic programs now outperform dermatologists in identifying melanoma. Robot journalists write sports and finance articles much faster than the average reporter. Longshoremen at ports were replaced with self-driving cranes.

${ }^{5}$ The idea that any increase in the output of each worker reduces the number of jobs is called the lump-of-labor fallacy. However, Acemoglu and Restrepo (2020) find that technological change of late has not created offsetting employment increases.
} 
Table 1. Public attitudes toward technology (WVS, United States, 2011)

\begin{tabular}{ll}
\hline Questions & Responses \\
\hline (1) The world is better off, or worse off, because of science and technology & 7.34 (mean), 8 (median) \\
(2) Science and technology are making our lives healthier, easier, and more comfortable & 7.19 (mean), 7 (median) \\
(3) Future changes: more emphasis on the development of technology is a bad thing & $6.9 \%$ agree \\
\hline
\end{tabular}

Note: $1=$ Strongly Disagree; $10=$ Strongly Agree.

advertisements on trade had also been predominately negative, emphasizing trade as a source of unemployment (Guisinger, 2017). Citizens' poor grasp of economic trends ${ }^{6}$ makes them particularly susceptible to framing effects (Dür, 2019). Although globalization is at the forefront of issues during elections, automation receives much less attention in most countries. In 2016, Clinton was the only major US presidential candidate who acknowledged the challenge of automation, but the issue was only mentioned six times on her campaign website of all materials she posted during the entire election cycle. Trump's senior advisors plainly rejected the role of automation in the decline of manufacturing. ${ }^{7}$

There are political motivations for elites to emphasize globalization over automation. First, the nature of globalization renders it convenient for elites to use group cues, a potent political tool. Outgroups, immigrants, and workers abroad, who are seemingly making considerable gains make clear and conceivable targets to blame. Political psychology research shows that group cues can trigger anxiety independently of the actual threat posed by the outgroup (Brader et al., 2008). Anxiety is known to cause behavioral changes that might be desired by politicians: anxious individuals are more likely to seek information, engage in protective responses, and vote. When people feel the need to compete for scarce resources, including jobs, they are more prone to see outgroup relations in zero-sum terms (Blumer, 1958; LeVine and Campbell, 1972). Automation, on the other hand, does not fit as neatly in the "us-versus-them" narrative, and no prominent politician has adopted such a frame so far.

Second, the lack of an "easy fix" makes automation an issue less ready for elites to politicize. It is, for example, relatively straightforward for politicians to convince citizens that a border wall and tighter visa restrictions will keep immigrants out, and imposing high tariffs will stop the influx of cheap imports. Nationalistic and ethnocentric sentiments also help justify the costs of such remedies. However, it requires much more effort to persuade citizens that increased efficiency and productivity due to computerization are undesirable and that impediments on innovation are suitable responses to the "problem."

\subsection{Predilection for technology and downplaying of technological threat}

Technology also makes for a poor target for attack because of the convenience it brings. According to the World Values Survey, a majority of Americans believe that science and technology make our lives easier and more comfortable (Table 1, Question 2). Few would trade a personal computer for a shared typist, the ATM machine for visits to a teller, or automatic exchanges for manual telephone switchboards-not even if the sacrifice would save an occupation. It is because most recognize that the world moves forward because of advances in science and technology (Question 1), and to retard innovation while the rest of the world promotes it would be unwise. A case against technological improvement would be politically difficult to

\footnotetext{
${ }^{6}$ In the United States, only 26 percent of respondents know that manufacturing output increased even as employment decreased (Pew Research Center, 2017). Americans also perceive the minority population to be much larger than it is in reality (Alba et al., 2005).

7“Scoring the Trump Economic Plan: Trade, Regulatory, and Energy Policy Impacts" was written by Peter Navarro and Wilbur Ross.
} 
make as only 6.9 percent of the respondents agree that more emphasis on the development of technology is bad (Question 3). Similar pro-technology sentiments are observed in most parts of the world.

The public's familiarity with technology helps explain the stark difference in attitudes toward machines during the Industrial Revolution and today. In recent history, workers have shown positive attitudes toward technology in the workplace. In an in-depth study of German workers, Thelen (1991) shows that labor unions and workers were "fundamentally receptive to technological changes," believing that firms' failure to adapt new technology would make them lose their competitiveness and eventually force them out of business. Milkman (1997) finds that technology vastly improved American autoworkers' work environments and they considered technology a "necessary evil" to ensure their company's survival. An Office of Technology Assessment of the United States (1983) report states that "willing acceptance" of new technology was the most common response of unions and their opposition to technology tended to disappear once union leaders were convinced that their members would not be negatively affected or would receive appropriate compensation if they were.

Not only do individuals welcome the benefits of technological change, but they also have a tendency to downplay its risks. Automation is not on the minds of most. Of the 3650 responses to an open-ended question about the most important problem facing the United States in the nationally representative 2016 ANES, only three mentioned automation or technology. When directly prompted, two-thirds of American respondents expect machines "to do much of the work currently done by humans within fifty years" (Pew Research Center, 2016). However, fourfifths of them think that their jobs will continue to exist in five decades. It is well documented in psychological research that people are more optimistic about their own prospects than those of others. In a study, college students believed that they were 50.2 percent more likely than their peers to land a job after graduation and 44.3 percent more likely to own a home (Weinstein, 1980). Unrealistic optimism or over-confidence is considered to be a defensive strategy motivated by a need to reduce anxiety. It may also be a result of cognitive biases. Individuals have a bias in recall-they are more likely to bring to mind personal actions, experiences, plans, and attributes that make favorable outcomes more likely for them, but they do not give the stereotypical person the same consideration (Tversky and Kahneman, 1974; Weinstein, 1980).

\subsection{Intense media attention and overestimation of the extent of globalization}

Although citizens downplay the risks of automation, journalists and the public tend to overstate the extent and downsides of globalization. The media sets the agenda and influences how issues are evaluated. Globalization is more heavily covered and scrutinized harder than automation. The often visible nature of offshoring - the image of a plant shutting down and relocating its operations-as opposed to automation which happens out of public view may have contributed to the discrepancy in reporting (Margalit, 2011).

News coverage of globalization also tends to emphasize its various problems and negative effects, such as employment concerns, factory closings, and safety and security risks. Analyzing over 40 years of trade news, Guisinger (2017) finds that "bad news" generate almost 40 percent more stories than "good news." Like journalists, the public responds more strongly to negative than positive news, potentially leading responsive governments to take overly aggressive measures (Soroka, 2006). Technological change in manufacturing, in comparison with international competition, is a trend that receives little media (and thus public) attention.

\subsection{Empirical expectations}

Due to the much higher salience of globalization and the public's predilection for technology, I expect that workers at risk of automation are more likely to attribute their economic anxieties 
to globalization, instead of technology. Empirically, the theory of blame displacement suggests that increased automation threat should be associated with more hostile views toward immigration (hypothesis 1), trade (hypothesis 2), and offshoring (hypothesis 3 ).

\section{Research design}

I use the 2016 ANES to examine these hypotheses. The ANES does not have a ready-to-use measure of occupation that is detailed enough to allow the matching of meaningful estimates of automation risks. I thus leverage individual responses to an open-ended question about their occupations. Respondents are asked to describe "the kind of work [they] do" and "[their] most important activities or duties at work." Based on these descriptions, I classified individuals into detailed occupation categories using the 2010 Standard Occupational Classification (SOC) system. In total, 2701 respondents provided descriptions of a current position and 2652 of them were assigned SOC codes. ${ }^{8}$ For example, individuals who describe their jobs as "server, wait tables" are coded as "waiters and waitresses (35-3031.00)." People who "take care of the elderly" are classified as "personal care aides (39-9021.00)." In cases where respondents describe duties that could fit multiple related occupations, I assign them multiple SOC codes. For instance, individuals whose jobs are "special education teacher" are coded as "special education teachers, preschool (25-2051.00)," "special education teachers, kindergarten and elementary school (25-2052.00)," "special education teachers, middle school (25-2053.00)," and "special education teachers, secondary school (25-2054.00)." Their risk of job automation is the average of the estimate of each of these occupations. ${ }^{9}$

There are two variables related to automation in the model. The first measures past levels of automation. The data comes from a survey administered by $\mathrm{O}^{\star} \mathrm{NET}$, which was sponsored by the Department of Labor. One of the questions asks a representative sample of job incumbents and occupation experts how automated their jobs are. Each SOC code has a corresponding subjectively assessed level of automation. It ranges from 0 to 1 , from not at all automated to fully automated. In the past, researchers had typically used indicators that measure the prevalence of routine tasks in an occupation. ${ }^{10}$ This self-reported data should provide a more accurate account of past levels of automation. Jobs sometimes remain manual because initial costs are prohibitive, not because it is technologically infeasible to automate. Job incumbents and experts are likely to have a better sense of the extent of automation on the ground. An individual holding a job with a high retrospective level of automation in our dataset means that he or she is working in an area where sweeping automation has occurred, but he or she continues to hold the job (e.g., to program machines). The important implication is that these individuals are likely to have witnessed automation in their workplace, but are the survivors, if not victors, of technological change.

The second and main independent variable is a prospective estimate of job automation risk. I adopt Frey and Osborne (2017) measure. This proxy indicates the risk of automation for each occupation with the expectation that automation will become more sophisticated and cheaper over the next decades, from 0 (not computerizable) to 1 (totally computerizable). The authors, together with a group of machine learning researchers, determined whether 70 occupations are automatable or not based on the detailed descriptions of tasks of occupations on $\mathrm{O}^{\star} \mathrm{NET}$, an online service developed for the Department of Labor. A Gaussian process classifier was then used to estimate the probability of computerization for other detailed occupations based on a training set hand-labeled by the researchers. An occupation is deemed susceptible to

\footnotetext{
${ }^{8}$ Among those who are not coded are individuals serving in the military or individuals who offered ambiguous, intelligible, or no information. About 94 percent of the respondents could be linked to the two measures of job automation threat.

${ }^{9}$ For a detailed explanation of the coding procedure, please refer to the online Appendix.

${ }^{10}$ The commonly used measure, routine task intensity (RTI) is only weakly correlated with actual levels of job automation at $r=0.17$. RTI is more strongly correlated with our measure of prospective job automation risk, whether a job is susceptible to automation in the future, at $r=0.68$.
} 


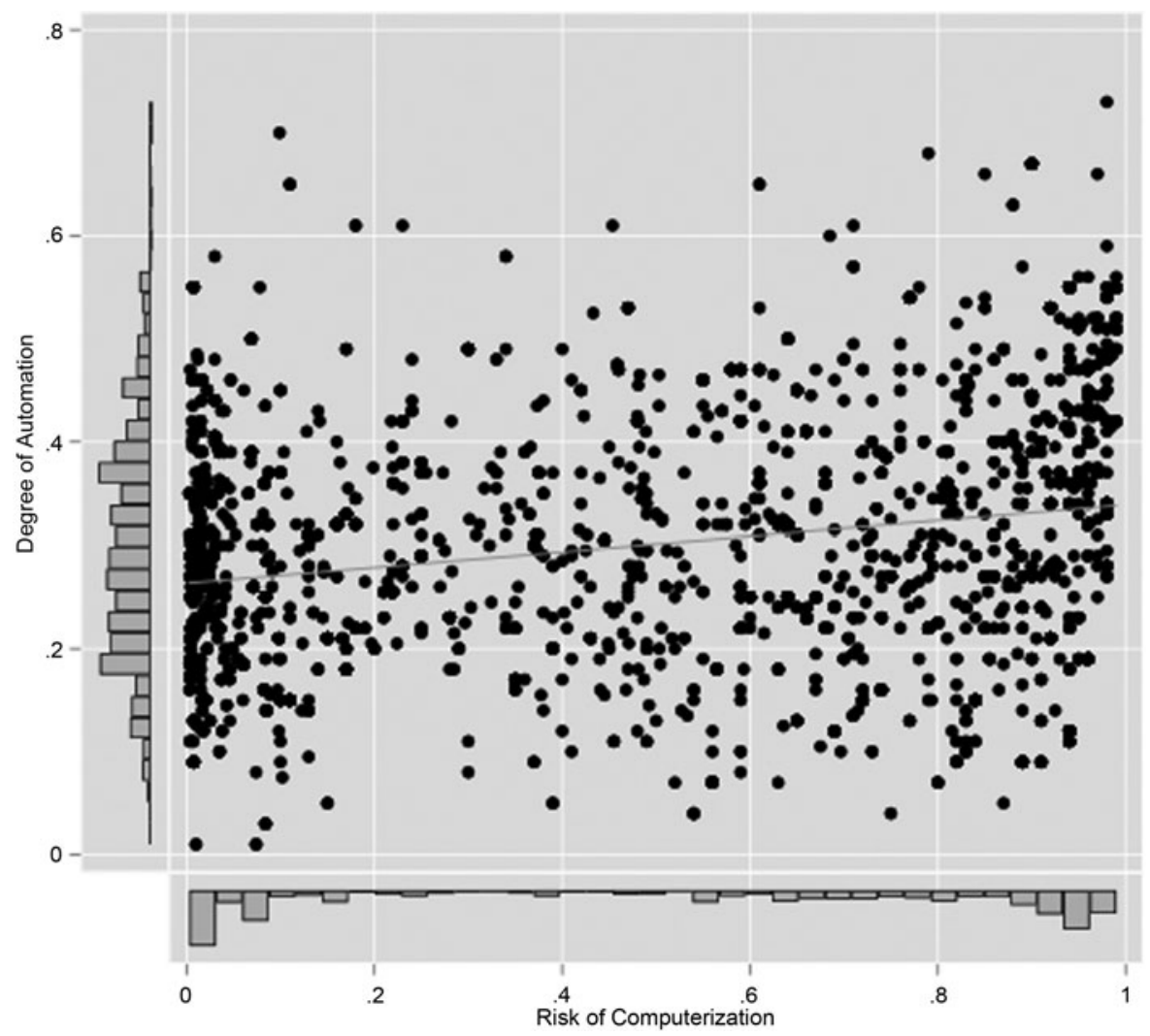

Figure 3. Degree of past automation and future automation risk.

Note: Retrospective and prospective measures of automation are only weakly correlated. The density plots show the distribution of the observations.

computerization if the tasks of the job can be sufficiently specified and performed by state-of-the-art computer-controlled equipment. They further consider the extent to which the automation of those tasks would require overcoming engineering bottlenecks such as perception and manipulation, creative intelligence, and social intelligence. For example, the job of a fashion designer is less computerizable and under a much lower threat than a court clerk because creativity is needed to perform the tasks of the former.

The retrospective and prospective indicators measure different dimensions and facets of workplace automation. Figure 3 shows that the extent to which jobs had already computerized and the likelihood of future automation are only very weakly correlated. Unlike in the past, automation is no longer confined to routine, well-defined tasks. Computers can now perform many tasks that were, not long ago, considered impossible to automate. Levy and Murnane (2005) wrote that drivers are immune from job automation because "it is hard to imagine discovering the set of rules that can replicate [a] driver's behavior." Little did they know that autonomous driving would become an area of intense engineering and machine learning focus. On the other hand, there are occupations that had been heavily computer-assisted but are unlikely to be completely automated in the near future, such as air traffic controllers and medical services managers.

The outcomes of interest are directly drawn from the ANES. ${ }^{11}$ The dependent variables include attitudes toward free trade agreements, immigration, and offshoring for individual $i$, in

${ }^{11}$ The specific questions used can be found in the online Appendix. 
occupation $j$, in industry $k$, and living in congressional district $l$. I regress individuals' attitudes on trade, immigration, and offshoring on these measures of automation. In addition, I control for the offshorability of individual $i$ 's job given their occupation $j$. I use Blinder and Krueger (2013)'s measure. ${ }^{12}$ An occupation is deemed not offshorable if its tasks must be performed at specific location, and require personal contact with end users. The measure ranges from 1 (not offshorable) to 5 (offshorable with minor or no difficulty or quality loss). I also hold constant the level of immigration in $i$ 's congressional district $l$ and import exposure in $i$ 's industry $k$. Level of immigration is defined as the size of the foreign-born population in a congressional district. Import penetration is operationalized as the total amount of imports over total sales in the United States in an industry (three-digit NAICS) (Owen and Johnston, 2017).

Furthermore, the model includes other variables known to affect $i$ 's policy attitudes and preferences-education, gender, age, family income, party identification, ethnocentrism, and nationalism. For ethnocentrism, I follow Kinder and Kam (2009)'s method of estimation. It is defined as the average of the three out-group thermometers subtracted from the in-group thermometer. Each respondent is in one of these four groups: Asians, Blacks, Hispanics, or Whites. Ethnocentrism and nationalism are distinct concepts. Although ethnocentrism relates to how one evaluates their own ethnic group vis-a-vis other groups, nationalism relates to one's feeling toward their own country. Individuals who are in the labor force, meaning those who are either employed or unemployed but looking for work, are included in the main analysis. Those who are not are excluded because they are no longer directly exposed to the automation risks. ${ }^{13}$

The data have a multilevel structure with four levels of analysis. To avoid biasing standard errors downward and producing spuriously "significant" effects, I adopt a multilevel ordered logistic model. ${ }^{14}$ The fully specified model is as follows:

$$
Y_{i j k l}=\alpha+\beta_{1} X_{i j k l}+\gamma_{1} Z_{j k l}+\theta_{1} V_{k l}+\lambda_{1} Q_{l}+\tau_{j}+\zeta_{k}+\mu_{l}+\epsilon_{i j k l}
$$

In this equation, $Y_{i j k l}$ are the outcomes of interest. $X_{i j k l}$ is a vector of individual-level covariates. $Z_{j k l}$ is a vector of occupational-level covariates. $V_{k l}$ is a vector of the industry-level covariate. $Q_{l}$ is a vector of the congressional district-level covariate. $\beta_{1}$ is the fixed effect parameter for individual-level covariates. $\gamma_{1}$ is the fixed effect parameter for occupational-level covariates. $\theta_{1}$ is the fixed effect parameter for the industry-level covariate. $\lambda_{1}$ is the fixed effect parameter for the congressional district-level covariate. $\tau_{j}, \zeta_{k}$, and $\mu_{l}$ are random intercepts. $\epsilon_{i j k l}$ is the error term.

\section{Results}

I report the main results in two ways. Table 2 presents results from multilevel ordered logistic regressions and Figure 4 features average marginal effects plots of the main variables of interest. In all, empirical analyses show that the threat of automation is linked to more intense hostility toward globalization, particularly immigration and trade. Table 2 shows that workers who are exposed to higher risks of automation are more likely to prefer tighter immigration restrictions (models 1 and 2) and oppose the negotiation of free trade agreements (models 3 and 4), providing support for hypotheses 1 and 2. These results hold in all model specifications, even with the addition of demographic and attitudinal controls. However, the relationship between automation risk

\footnotetext{
${ }^{12}$ I followed their codebook to code the offshorability of occupations that were not coded in the PDII survey. My additions did not change the results.

${ }^{13}$ I have analyzed individuals who are no longer in the labor force for additional insights. I note these exceptions in the text and relevant tables.

${ }^{14}$ I used ordered logistic regression for some subsample analyses where certain levels of data are dropped. I specify those instances in the findings section.
} 
Table 2. Attitudes toward globalization (workers in labor force)

\begin{tabular}{|c|c|c|c|c|c|c|}
\hline & \multicolumn{2}{|c|}{ Reduce immigration } & \multicolumn{2}{|c|}{ Oppose trade } & \multicolumn{2}{|c|}{ Discourage outsourcing } \\
\hline & (1) & $(2)$ & (3) & (4) & (5) & (6) \\
\hline Risk of computerization & $\begin{array}{l}0.82^{\star \star \star} \\
(0.20)\end{array}$ & $\begin{array}{l}0.46^{\star \star} \\
(0.15)\end{array}$ & $\begin{array}{l}0.75^{\star \star \star} \\
(0.12)\end{array}$ & $\begin{array}{c}0.32^{\star} \\
(0.14)\end{array}$ & $\begin{array}{c}0.06 \\
(0.18)\end{array}$ & $\begin{array}{c}0.20 \\
(0.19)\end{array}$ \\
\hline Past level of automation & $\begin{array}{c}0.47 \\
(0.46)\end{array}$ & $\begin{array}{c}0.18 \\
(0.43)\end{array}$ & $\begin{array}{c}-1.34^{\star \star \star} \\
(0.38)\end{array}$ & $\begin{array}{c}-0.89^{\star} \\
(0.43)\end{array}$ & $\begin{array}{c}0.83 \\
(0.58)\end{array}$ & $\begin{array}{c}0.24 \\
(0.58)\end{array}$ \\
\hline Offshorability & & $\begin{array}{c}0.01 \\
(0.04)\end{array}$ & & $\begin{array}{c}0.05 \\
(0.04)\end{array}$ & & $\begin{array}{c}0.06 \\
(0.05)\end{array}$ \\
\hline Import penetration & & $\begin{array}{c}-0.16 \\
(0.18)\end{array}$ & & $\begin{array}{c}-0.26 \\
(0.19)\end{array}$ & & $\begin{array}{c}-0.00 \\
(0.23)\end{array}$ \\
\hline Foreign born & & $\begin{array}{c}-1.88^{\star \star \star} \\
(0.50)\end{array}$ & & $\begin{array}{c}-1.37^{\star \star} \\
(0.45)\end{array}$ & & $\begin{array}{r}-1.44^{\star} \\
(0.62)\end{array}$ \\
\hline Gender (male) & & $\begin{array}{r}-0.22^{*} \\
(0.10)\end{array}$ & & $\begin{array}{c}-0.25^{\star *} \\
(0.09)\end{array}$ & & $\begin{array}{c}-0.10 \\
(0.12)\end{array}$ \\
\hline Party ID (GOP) & & $\begin{array}{l}0.30^{\star \star \star} \\
(0.03)\end{array}$ & & $\begin{array}{l}0.12^{\star \star \star} \\
(0.02)\end{array}$ & & $\begin{array}{c}0.07^{\star} \\
(0.03)\end{array}$ \\
\hline Age & & $\begin{array}{l}0.02^{\star \star \star} \\
(0.00)\end{array}$ & & $\begin{array}{r}-0.01^{*} \\
(0.00)\end{array}$ & & $\begin{array}{l}0.02^{\star \star} \\
(0.01)\end{array}$ \\
\hline Education & & $\begin{array}{c}-0.08^{\star \star} \\
(0.03)\end{array}$ & & $\begin{array}{c}-0.14^{\star \star \star} \\
(0.02)\end{array}$ & & $\begin{array}{c}0.01 \\
(0.03)\end{array}$ \\
\hline Nationalism & & $\begin{array}{l}0.26^{\star \star \star} \\
(0.05)\end{array}$ & & $\begin{array}{c}0.03 \\
(0.04)\end{array}$ & & $\begin{array}{c}-0.04 \\
(0.05)\end{array}$ \\
\hline Ethnocentrism & & $\begin{array}{l}2.64^{\star \star \star} \\
(0.34)\end{array}$ & & $\begin{array}{c}0.37 \\
(0.25)\end{array}$ & & $\begin{array}{c}-0.09 \\
(0.32)\end{array}$ \\
\hline Family income & & $\begin{array}{c}0.01 \\
(0.01)\end{array}$ & & $\begin{array}{c}-0.00 \\
(0.01)\end{array}$ & & $\begin{array}{c}0.01 \\
(0.01)\end{array}$ \\
\hline $\operatorname{var}($ Intercept$[\mathrm{occ}])$ & $\begin{array}{c}0.00 \\
(0.00)\end{array}$ & $\begin{array}{c}0.00 \\
(0.00)\end{array}$ & $\begin{array}{c}0.02 \\
(0.05)\end{array}$ & $\begin{array}{c}0.00 \\
(0.00)\end{array}$ & $\begin{array}{c}0.17 \\
(0.12)\end{array}$ & $\begin{array}{c}0.13 \\
(0.11)\end{array}$ \\
\hline $\operatorname{var}($ Intercept[occ>ind]) & $\begin{array}{c}0.00 \\
(0.00)\end{array}$ & $\begin{array}{c}0.00 \\
(0.00)\end{array}$ & $\begin{array}{c}0.09 \\
(0.10)\end{array}$ & $\begin{array}{c}0.09 \\
(0.11)\end{array}$ & $\begin{array}{c}0.00 \\
(0.00)\end{array}$ & $\begin{array}{c}0.00 \\
(0.00)\end{array}$ \\
\hline $\operatorname{var}($ Intercept $[$ occ >ind >cd] $)$ & $\begin{array}{c}1.97 \\
(1.66)\end{array}$ & $\begin{array}{c}0.26 \\
(0.48)\end{array}$ & $\begin{array}{c}0.00 \\
(0.00)\end{array}$ & $\begin{array}{c}0.00 \\
(0.00)\end{array}$ & $\begin{array}{c}1.05 \\
(1.63)\end{array}$ & $\begin{array}{c}0.48 \\
(1.36)\end{array}$ \\
\hline Observations & 2073 & 1811 & 2059 & 1801 & 2076 & 1814 \\
\hline
\end{tabular}

Note: Results from multilevel ordered logistic regressions of globalization attitudes on hypothesized determinants. Standard errors are in parentheses. ${ }^{\star} p<0.05,{ }^{\star \star} p<0.01,{ }^{\star \star \star} p<0.001$.

and attitudes toward offshoring (models 5 and 6) is not statistically significant, but is in the expected direction. It may be due to the fact that there is little variation in the dependent variable. An overwhelming majority, 70 percent, of the respondents believe that the government should discourage companies from hiring workers abroad. Only 4 percent think that the government should encourage offshoring. This animus view toward offshoring is in line with findings in Mansfield and Mutz (2013).

The confidence intervals of the average marginal effects of automation risk on immigration and trade attitudes do not overlap with zero (Figure 4). Especially, considering the real-world context, these effects are substantively important. Research thus far shows that the adverse impact of job automation is unevenly distributed (e.g., conditional on educational attainment) and will likely grow stronger in the years to come (Frey and Osborne, 2017; Kurer and Palier, 2019; Gallego et al., Forthcoming). Automation's impact is also expected to be geographically concentrated and will likely hit the industrialized Midwest and several low-wage metropolitan areas the hardest. There is evidence that robot exposure had swung the 2016 presidential election in favor of the more radical anti-status quo candidate (Frey et al., 2018). Observing a similar phenomenon, Im et al. (2019) find that automation threat increased support for radical right parties in 11 West European countries. A revival of radical politics fueled by outgroup scapegoating may cause long-lasting damages to the international system. 

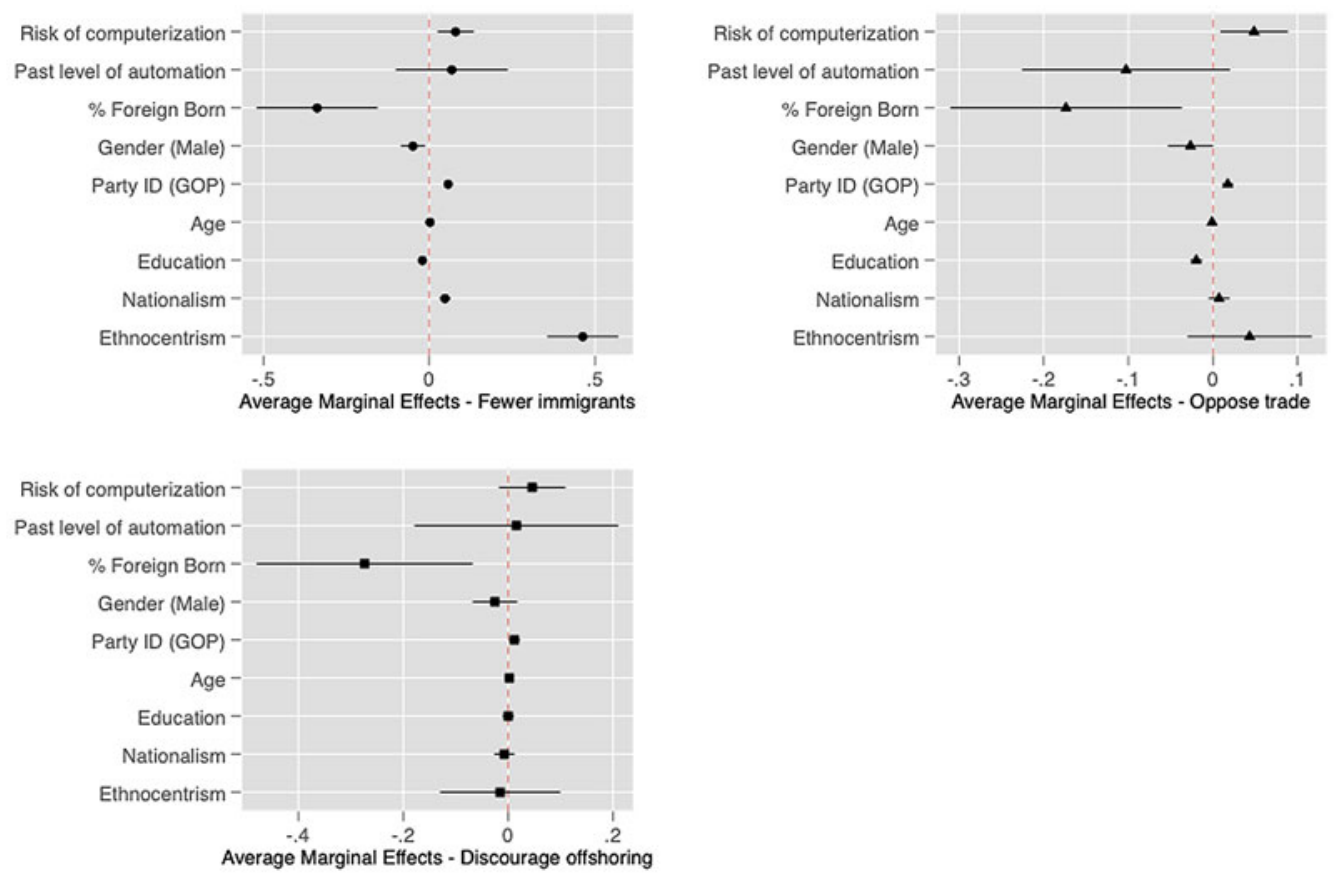

Figure 4. Average marginal effects for key variables predicting attitudes.

Note: Average marginal effects based on ordered logistic regressions of attitudes toward globalization and technology on hypothesized determinants. This sample includes Americans in the labor force.

Overall, the effects of various control variables are consistent with our conventional understanding of their influences on globalization attitudes: education is negatively associated with protectionist sentiments, nationalism and ethnocentrism strongly correlates with immigrant hostility; and female respondents are more protectionist. There are two ostensible anomalies. First, strong Republicans are more likely to be anti-trade and anti-immigration than Democrats. In 2016, self-identified Republicans' trade positions are inconsistent with those long held by the party itself (Karol, 2000; Irwin, 2020), but they are consistent with those held by the presidential candidate of their party in the election, who controlled much of the narrative. Second, job offshorability and globalization attitudes do not share statistically significant relationships. Owen and Johnston (2017) and Kaihovaara and Im (2020), using European samples, find that offshorability conditions the effect of technological risks on globalization attitudes. However, in this American sample, I do not find such an effect using an interaction term of automation susceptibility and offshorability. ${ }^{15}$

Additional robustness checks can be found in the online Appendix (A.1). Findings do not change meaningfully with a different estimation method and weights. These findings together offer evidence for the theory that workers facing higher risks of automation tend to displace their blame toward globalization. At-risk workers are more likely to oppose trade agreements and favor immigration restrictions, even after accounting for conventional explanations for these attitudes. ${ }^{16}$

\footnotetext{
${ }^{15}$ This paper uses Frey and Osborne's measure of automation risk, while Owen and Johnston (2017) and Kaihovaara and Im (2020) use the routine task intensity (RTI) index.

${ }^{16}$ For an exploratory analysis on how automation threat affects technology attitudes, refer to online Appendix A.7. In short, automation risk does not appear to predict attitudes toward technology, as measured by support for government STEM spending.
} 
Table 3. Attitudes toward globalization and technology (potentially displaced individuals)

\begin{tabular}{|c|c|c|c|}
\hline & $\begin{array}{l}\text { Oppose trade } \\
\text { (7) }\end{array}$ & $\begin{array}{l}\text { Reduce immigration } \\
\text { (8) }\end{array}$ & $\begin{array}{l}\text { Discourage outsource } \\
\text { (9) }\end{array}$ \\
\hline Past level of automation & $\begin{array}{r}1.08^{\star} \\
(0.50)\end{array}$ & $\begin{array}{l}1.39^{\star \star} \\
(0.52)\end{array}$ & $\begin{array}{l}-0.15 \\
(0.59)\end{array}$ \\
\hline Foreign born & $\begin{array}{l}-3.03^{\star * \star} \\
(0.64)\end{array}$ & $\begin{array}{l}-2.38^{\star \star \star} \\
(0.66)\end{array}$ & $\begin{array}{c}-0.90 \\
(0.74)\end{array}$ \\
\hline Gender (male) & $\begin{array}{r}-0.20 \\
(0.12)\end{array}$ & $\begin{array}{c}-0.11 \\
(0.12)\end{array}$ & $\begin{array}{c}-0.23 \\
(0.14)\end{array}$ \\
\hline Party ID (GOP) & $\begin{array}{l}0.10^{\star \star \star} \\
(0.03)\end{array}$ & $\begin{array}{l}0.32^{\star \star \star} \\
(0.03)\end{array}$ & $\begin{array}{l}0.01 \\
(0.03)\end{array}$ \\
\hline Age & $\begin{array}{r}-0.01^{\star} \\
(0.00)\end{array}$ & $\begin{array}{c}0.01^{*} \\
(0.00)\end{array}$ & $\begin{array}{c}0.01 \\
(0.00)\end{array}$ \\
\hline Education & $\begin{array}{l}-0.12^{\star \star \star} \\
(0.03)\end{array}$ & $\begin{array}{l}-0.09^{\star \star \star} \\
(0.03)\end{array}$ & $\begin{array}{c}-0.02 \\
(0.03)\end{array}$ \\
\hline Nationalism & $\begin{array}{l}0.08 \\
(0.05)\end{array}$ & $\begin{array}{l}0.20^{\star \star \star} \\
(0.06)\end{array}$ & $\begin{array}{l}0.03 \\
(0.06)\end{array}$ \\
\hline Ethnocentrism & $\begin{array}{c}-0.05 \\
(0.35)\end{array}$ & $\begin{array}{l}2.82^{\star \star \star} \\
(0.38)\end{array}$ & $\begin{array}{c}-0.33 \\
(0.40)\end{array}$ \\
\hline Observations & 987 & 995 & 993 \\
\hline
\end{tabular}

Note: Results from ordered logistic regressions of globalization attitudes on hypothesized determinants. Standard errors are in parentheses. ${ }^{*} p<0.05,{ }^{\star \star} p<0.01,{ }^{\star \star \star} p<0.001$. Respondents included in this analysis are those who are working in non-tradable sectors as defined by Blinder and Krueger (2013).

Table 4. Attitudes toward globalization and tech spending (workers in non-tradable sector)

\begin{tabular}{|c|c|c|c|c|c|c|}
\hline & \multicolumn{2}{|c|}{ Reduce immigration } & \multicolumn{2}{|c|}{ Oppose trade } & \multicolumn{2}{|c|}{ Discourage outsourcing } \\
\hline & (10) & (11) & $(12)$ & (13) & (14) & (15) \\
\hline Risk of computerization & $\begin{array}{l}0.60^{\star \star \star} \\
(0.14)\end{array}$ & $\begin{array}{l}0.50^{\star *} \\
(0.17)\end{array}$ & $\begin{array}{l}0.59^{\star \star \star} \\
(0.14)\end{array}$ & $\begin{array}{c}0.35^{\star} \\
(0.17)\end{array}$ & $\begin{array}{c}0.27 \\
(0.16)\end{array}$ & $\begin{array}{l}0.55^{\star \star} \\
(0.20)\end{array}$ \\
\hline Past level of automation & $\begin{array}{c}0.57 \\
(0.48)\end{array}$ & $\begin{array}{c}0.21 \\
(0.52)\end{array}$ & $\begin{array}{c}-1.27^{\star \star} \\
(0.48)\end{array}$ & $\begin{array}{c}-0.95 \\
(0.52)\end{array}$ & $\begin{array}{c}0.50 \\
(0.56)\end{array}$ & $\begin{array}{c}0.30 \\
(0.62)\end{array}$ \\
\hline Import penetration & & $\begin{array}{c}-0.03 \\
(0.21)\end{array}$ & & $\begin{array}{c}-0.27 \\
(0.24)\end{array}$ & & $\begin{array}{c}0.11 \\
(0.28)\end{array}$ \\
\hline Foreign born & & $\begin{array}{r}-1.43^{\star} \\
(0.58)\end{array}$ & & $\begin{array}{c}-1.37^{\star} \\
(0.58)\end{array}$ & & $\begin{array}{c}-1.77^{\star \star} \\
(0.65)\end{array}$ \\
\hline Gender (male) & & $\begin{array}{c}-0.20 \\
(0.12)\end{array}$ & & $\begin{array}{c}-0.19 \\
(0.11)\end{array}$ & & $\begin{array}{c}-0.05 \\
(0.13)\end{array}$ \\
\hline Party ID (GOP) & & $\begin{array}{l}0.27^{\star \star *} \\
(0.03)\end{array}$ & & $\begin{array}{l}0.11^{\star \star *} \\
(0.03)\end{array}$ & & $\begin{array}{l}0.09^{\star *} \\
(0.03)\end{array}$ \\
\hline Age & & $\begin{array}{l}0.01^{\star \star \star} \\
(0.00)\end{array}$ & & $\begin{array}{c}-0.01 \\
(0.00)\end{array}$ & & $\begin{array}{l}0.02^{\star \star \star} \\
(0.00)\end{array}$ \\
\hline Education & & $\begin{array}{c}-0.05 \\
(0.03)\end{array}$ & & $\begin{array}{c}-0.10^{\star \star \star} \\
(0.03)\end{array}$ & & $\begin{array}{c}0.05 \\
(0.03)\end{array}$ \\
\hline Nationalism & & $\begin{array}{l}0.28^{\star * *} \\
(0.05)\end{array}$ & & $\begin{array}{c}0.03 \\
(0.05)\end{array}$ & & $\begin{array}{c}-0.00 \\
(0.06)\end{array}$ \\
\hline Ethnocentrism & & $\begin{array}{l}2.10^{\star \star \star} \\
(0.33)\end{array}$ & & $\begin{array}{c}0.38 \\
(0.30)\end{array}$ & & $\begin{array}{c}-0.13 \\
(0.35)\end{array}$ \\
\hline Family income & & $\begin{array}{c}0.01 \\
(0.01)\end{array}$ & & $\begin{array}{c}0.00 \\
(0.01)\end{array}$ & & $\begin{array}{c}0.02 \\
(0.01)\end{array}$ \\
\hline Observations & 1294 & 1124 & 1290 & 1119 & 1299 & 1127 \\
\hline
\end{tabular}

Note: Results from ordered logistic regressions of globalization attitudes on hypothesized determinants. Standard errors are in parentheses. ${ }^{\star} p<0.05,{ }^{\star \star} p<0.01,{ }^{\star \star \star} p<0.001$. Respondents included in this analysis are those who are working in non-tradable sectors as defined by Blinder and Krueger (2013).

\subsection{Further discussion and subgroup analyses}

There are other findings and potential challenges to the paper that merit further discussion. At the first glance, it may seem counterintuitive that automation exposure in the past is not linked to 

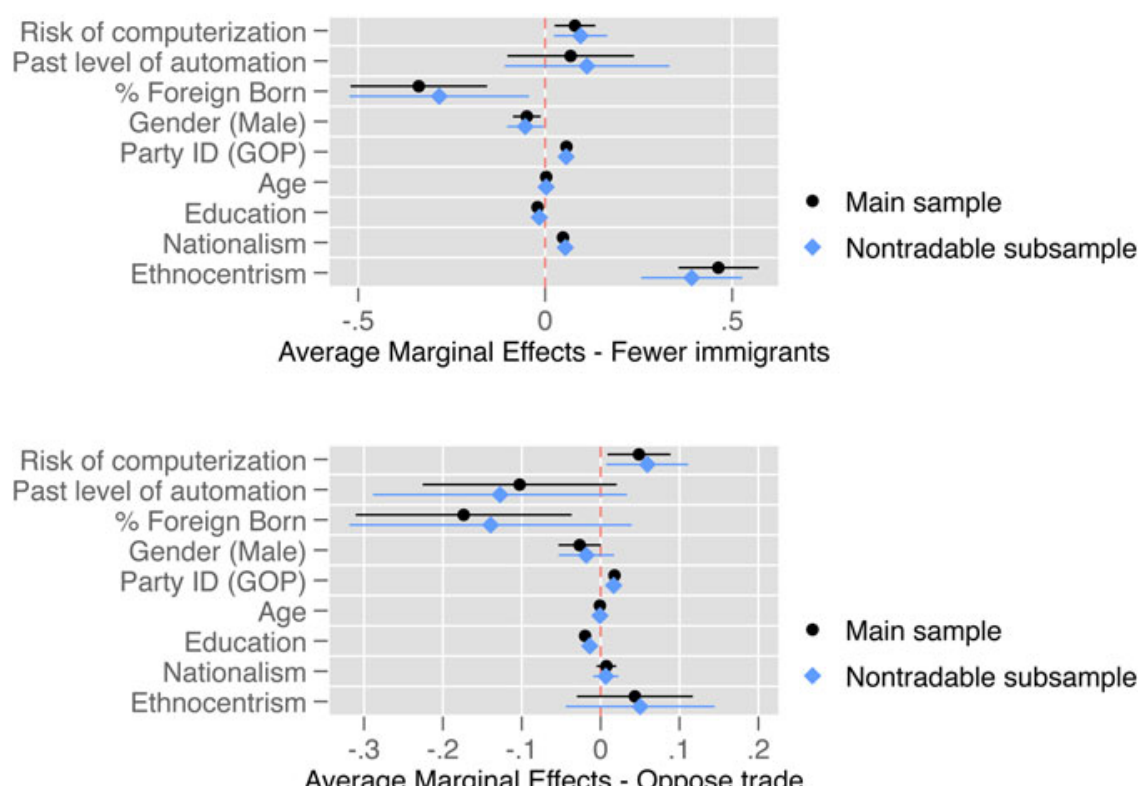

Average Marginal Effects - Oppose trade

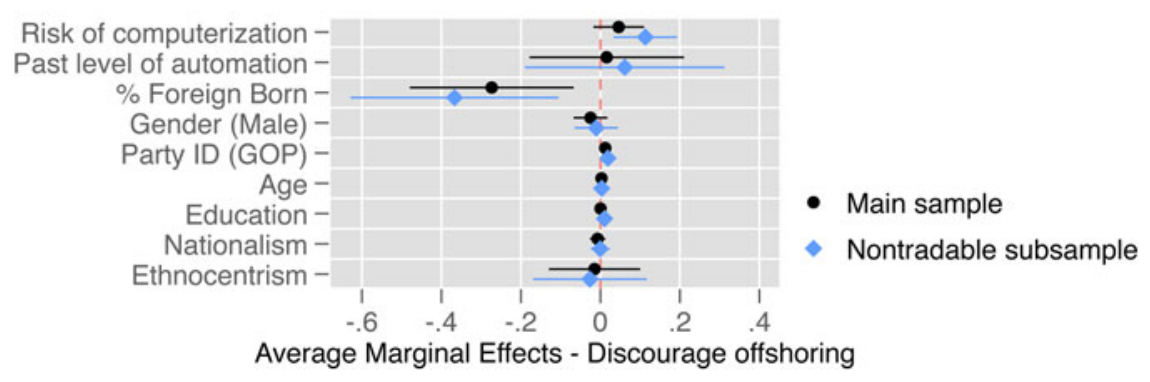

Figure 5. Average marginal effects for key variables predicting attitudes (full and non-tradable subsample). Note: Average marginal effects based on ordered logistic regressions of attitudes toward globalization and technology on hypothesized determinants. This main sample includes Americans in the labor force, the non-tradable subsample includes workers in the nontradable sector as defined by Blinder and Krueger (2013).

immigration hostility (models 1 and 2, Table 2) and is even associated with more positive views toward free trade (models 3 and 4, Table 2). It is worth highlighting that workers in this analysis are still in the labor force and had most likely "survived" automation. ${ }^{17}$ If computerization and mechanization are conducive to higher productivity and enhanced competitiveness, workers who are currently in more automated occupations may have an edge in the international market, making them not merely the survivors of technological change but also the winners of it. Among those who survived, animosity toward economic outgroups is driven not by past levels of computerization, but the prospective threat of automation.

Admittedly, the existing survey data limit our ability to trace and identify workers who did not survive technological change. Although the ANES is administered regularly, it is not a panel survey. Given these constraints, I leverage information on respondents' past occupations for a preliminary analysis of the relationship between past automation and globalization attitudes among individuals who might have been displaced by technology. This analysis includes those

\footnotetext{
${ }^{17}$ The size of the coefficient is even larger if we exclude the group of workers who are unemployed within the labor force.
} 
who are no longer in the labor force or are currently unemployed but seeking work. These individuals must have had at least a job in the past to be included in the sample, as a job is the prerequisite for automation exposure. As we do not know when these workers might have been displaced, certain time-dependent covariates (e.g., import exposure at the time of displacement) have to be dropped. The variable measuring prospective risk of automation is also moot. Results in Table 3 show that past levels of automation have a statistically significant effect on protectionist trade and immigration policy preferences. ${ }^{18}$ This suggests that probable losers of technological change are more opposed to globalization.

However, there may be reasons for us to believe that automation and globalization are related processes. If this is true, how do we know that losers of technological change adopt more protectionist policy preferences as a result of blame displacement, but not because of a rational response to material losses due to globalization? Although the structure of the ANES limits identification options, I reanalyze the data with only a subsample of Americans who worked in non-tradable sectors (as defined in Blinder and Krueger, 2013). Examples of non-tradable occupations are teachers, firefighters, and restaurant servers. The intuition is that workers in non-tradable sectors are only minimally affected by import competition, and thus should have few economic reasons to be against trade. They may even favor trade in their capacities as consumers (Naoi and Kume, 2015). If we observe stronger hostility toward trade among workers exposed to higher threats of automation in this subsample, there are stronger reasons for us to believe that outgroup scapegoating may be at play.

Using the same ANES data, Table 4 shows that workers in non-tradable sectors facing higher threats of job automation are still more likely to support immigration restrictions, oppose free trade agreements, and prefer the government to discourage offshoring. These findings are robust and consistent across five out of six models, with and without controls. Figure 5 presents combined plots of average marginal effects for key variables predicting attitudes for both the main sample comprising all workers in the labor force and the non-tradable subsample. The magnitudes of effect of automation risk on attitudes are comparable or larger in the subsample than in the main sample. The consistent findings offer additional evidence that hostility toward globalization is related to anxiety about future job automation.

\section{Conclusion}

The existing scholarship on structural economic change emphasizes the impact of technology on wages and employment. Although immigration and trade only account for a small percentage of layoffs, globalization takes the brunt of the blame for labor market anxieties (Card, 1990; Peri and Sparber, 2009; Ottaviano et al., 2013; Helpman, 2018). Although decades of studies in economics have documented the distributional consequences of technology related to employment, income, inequality, and health, the political effects of automation are not well understood. This paper contributes to the nascent literature by examining the impact of automation on public opinion on globalization and technological change. Using a nationally representative survey, it shows that automation threat may have intensified globalization resistance. Workers who are threatened by automation are prone to displacing blame for labor market threats toward immigrants and foreign workers. This misattribution of blame is due to politically motivated framing by elites to reinforce ingroup and outgroup differences, the visibility of globalization-induced job losses relative to technological displacement, and the public's predilection for technology. Although this paper features a single-country study of the United States, these conditions for blame misattribution are present across much of the developed world.

To evaluate the theory empirically, I analyzed the American National Election Studies. I leveraged answers to an open-ended question about individuals' occupations to assess their automation

\footnotetext{
${ }^{18}$ Again, automation exposure has no statistically meaningful impact on views toward outsourcing, possibly due to low variation in the dependent variable.
} 
risks. I found that workers facing higher risks of automation are more likely to oppose free trade agreements and favor immigration restrictions, even after accounting for conventional explanations for these attitudes. These results are robust and consistent across different models and model specifications. The impact of automation threat on attitudes toward production offshoring, however, is not statistically significant. It might be attributable to the low variation in opinion toward offshoring, which is predominately adverse. A subsample analysis of individuals in non-tradable sectors provides additional evidence of blame misattribution. Even for those who are minimally affected by trade, automation threat is associated with protectionist policy preferences. Overall, the evidence suggests that automation anxiety increases attempts to resist globalization.

The theory of blame misattribution has important implications for debates over the determinants of globalization attitudes. The premise in open economy politics that economic self-interest shapes individual preferences was once regarded as conventional wisdom. Later research challenges the notion and suggests that non-economic factors, such as ethnocentrism and racism, rather than pocketbook concerns, determine preferences toward globalization. This paper shows that grievances against globalization have economic origins, but it calls into question the standard assumption that individuals understand and can correctly identify the sources of their economic anxieties. Anti-globalization attitudes are based on the beliefs, but not necessarily the reality, that foreign outgroups are the sources of their economic anxieties. Given these believes, demands for protectionist policies are motivated by self-interest regardless of whether these policies actually address their economic concerns.

Correct blame attribution is important for three main reasons. First, the misplacement of hostility toward globalization can lead to collective decisions that might be economically detrimental and difficult to be reversed, such as the fracturing of international political and economic unions (e.g., Brexit) and the election of political leaders who have protectionist agendas and the executive power to reverse trade liberalization. Second, the misattribution of blame may lead to poor policy outcomes. If free trade and immigration are linked to overall welfare gains, responding to technological change with protectionism may hurt constituencies that derive key benefits from globalization. Protection may even hurt those who demand these policies in the first place if they misidentified the source of their economic problems. Finally, it is only through the understanding of the real challenge to work that citizens can better prepare themselves for the advent of large-scale job automation. Knowledge of the threat of automation will also motivate more informed discussions about appropriate adjustment and compensation measures for displaced labor.

Supplementary material. The supplementary material for this article can be found at https://doi.org/10.1017/psrm.2021.43.

Acknowledgments. I thank Ted Brader, Mary Gallagher, Gary Herrigel, Anil Menon, James Morrow, Iain Osgood, Sergi Pardos-Prado, Emmanuel Teitelbaum, Clayton Webb, Stan Wong, Yujeong Yang, and participants at the 2017 Varieties of Backlash Workshop, the 2018 Pacific International Politics Conference, the 2018 APSA Annual Meeting, the 2018 Peace Science Society International Annual Meeting, the 2019 EPSA Annual Meeting, Michigan's Political Economy Workshop, and Princeton's International Relations Faculty Colloquium for their thoughtful suggestions.

\section{References}

Acemoglu D and Restrepo P (2018) The race between man and machine: implications of technology for growth, factor shares, and employment. American Economic Review 108, 1488-1542.

Acemoglu D and Restrepo P (2020) Robots and jobs: evidence from US labor markets. Journal of Political Economy 128, 2188-2244.

Alba R, Rumbaut RG and Marotz K (2005) A distorted nation: perceptions of racial/ethnic group sizes and attitudes toward immigrants and other minorities. Social Forces 84, 901-919.

Bekman E, Bound J and Machin S (1998) Implications of skill-biased technological change: international evidence. The Quarterly Journal of Economics 113, 1245-1279.

Blinder AS and Krueger AB (2013) Alternative measures of offshorability: a survey approach. Journal of Labor Economics 31, S97-S128.

Blumer H (1958) Race prejudice as a sense of group position. Pacific Sociological Review 1, 3-7.

Borjas GJ (1995) The economic benefits from immigration. Journal of Economic Perspectives 9, 3-22. 
Brader T, Valentino NA and Suhay E (2008) What triggers public opposition to immigration? Anxiety, group cues, and immigration threat. American Journal of Political Science 52, 959-978.

Card D (1990) The impact of the Mariel boatlift on the Miami labor market. ILR Review 43, 245-257.

Di Tella R and Rodrik D (2020) Labour market shocks and the demand for trade protection: evidence from online surveys. The Economic Journal 130, 1008-1030.

Dür A (2019) How interest groups influence public opinion: arguments matter more than the sources. European Journal of Political Research 58, 514-535.

Feenstra RC, Ma H and Xu Y (2019) US exports and employment. Journal of International Economics 120, 46-58.

Freeman RB (1995) Are your wages set in Beijing? Journal of Economic Perspectives 9, 15-32.

Frey CB and Osborne MA (2017) The future of employment: how susceptible are jobs to computerisation? Technological Forecasting and Social Change 114, 254-280.

Frey CB, Berger T and Chen C (2018) Political machinery: did robots swing the 2016 US presidential election? Oxford Review of Economic Policy 34, 418-442.

Gallego A, Kurer T and Schöll N (Forthcoming) Neither left-behind nor superstar: ordinary winners of digitalization at the ballot. Journal of Politics. https://www.journals.uchicago.edu/doi/10.1086/714920.

Goldstein JL and Peters ME (2014) Nativism or economic threat: attitudes toward immigrants during the great recession. International Interactions 40, 376-401.

Goos M and Manning A (2007) Lousy and lovely jobs: the rising polarization of work in Britain. The Review of Economics and Statistics 89, 118-133.

Guisinger A (2017) American Opinion on Trade: Preferences without Politics. New York: Oxford University Press.

Hays JC, Ehrlich SD and Peinhardt C (2005) Government spending and public support for trade in the OECD: an empirical test of the embedded liberalism thesis. International Organization 59, 473-494.

Helpman E (2018) Globalization and Inequality. Cambridge, MA: Harvard University Press.

Hicks MJ and Devaraj S (2015) The myth and the reality of manufacturing in America. Tech. rep., Center for Business and Economic Research, Ball State University. Available at https://conexus.cberdata.org/files/MfgReality.pdf.

Im ZJ, Mayer N, Palier B and Rovny J (2019) The "losers of automation": a reservoir of votes for the radical right?. Research \& Politics 6, 2053168018822395.

Irwin DA (2020) Free Trade Under Fire. Princeton, NJ: Princeton University Press.

Kaihovaara A and Im ZJ (2020) Jobs at risk? Task routineness, offshorability, and attitudes toward immigration. European Political Science Review 12, 327-345.

Karol D (2000) Divided government and US trade policy: much ado about nothing? International Organization $\mathbf{5 4}$ 825-844.

Kinder DR and Kam CD (2009) Us against Them: Ethnocentric Foundations of American Opinion. Chicago and London: University of Chicago Press.

Kurer T and Palier B (2019) Shrinking and shouting: the political revolt of the declining middle in times of employment polarization Research \& Politics 6, 2053168019831164.

LeVine RA and Campbell DT (1972) Ethnocentrism: Theories of Conflict, Ethnic Attitudes, and Group Behavior. New York: John Wiley \& Sons.

Levy F and Murnane RJ (2005) The New Division of Labor: How Computers are Creating the Next Job Market. Princeton and Oxford: Princeton University Press.

Mader M, Steiner ND and Schoen H (2020) The globalisation divide in the public mind: belief systems on globalisation and their electoral consequences. Journal of European Public Policy 27, 1526-1545.

Mansfield ED and Mutz DC (2013) Us versus them: mass attitudes toward offshore outsourcing. World Politics 65, 571-608.

Margalit Y (2011) Costly jobs: trade-related layoffs, government compensation, and voting in US elections. American Political Science Review 105, 166-188.

Milkman R (1997) Farewell to the Factory: Auto Workers in the Late Twentieth Century. Berkeley, Los Angeles, London: Univ of California Press.

Naoi M and Kume I (2015) Workers or consumers? A survey experiment on the duality of citizens' interests in the politics of trade. Comparative Political Studies 48, 1293-1317.

Office of Technology Assessment of the United States (1983) Automation and the workplace : selected labor, education, and training issues: a technical memorandum. Available at https://ota.fas.org/reports/8304.pdf.

Ottaviano GI, Peri G and Wright GC (2013) Immigration, offshoring, and American jobs. American Economic Review 103, 1925-59.

Owen E and Johnston NP (2017) Occupation and the political economy of trade: job routineness, offshorability, and protectionist sentiment. International Organization 71, 665-699.

Peri G and Sparber C (2009) Task specialization, immigration, and wages. American Economic Journal: Applied Economics 1, 135-69.

Peri G and Yasenov V (2019) The labor market effects of a refugee wave synthetic control method meets the mariel boatlift. Journal of Human Resources 54, 267-309. 
Pew Research Center (2016) Public predictions for the future of workforce automation. https://www.pewresearch.org/internet/ 2016/03/10/public-predictions-for-the-future-of-workforce-automation/.

Pew Research Center (2017) Most Americans unaware that as U.S. manufacturing jobs have disappeared, output has grown. https://www.pewresearch.org/fact-tank/2017/07/25/most-americans-unaware-that-as-u-s-manufacturing-jobs-have-disappearedoutput-has-grown/.

Rho S and Tomz M (2017) Why don't trade preferences reflect economic self-interest? International Organization 71, S85-S108.

Schaffer L and Spilker G (2016) Adding another level: individual responses to globalization and government welfare policies. Political Science Research and Methods 4, 399-426.

Scheve KF, Slaughter MJ and Slaughter M (2001) Globalization and the Perceptions of American Workers. Washington, DC: Institute for International Economics. https://www.google.com/books/edition/Globalization_and_the_Perceptions_of_Ame/ fw5CCu9uGTwC?hl=en\&gbpv=0.

Semyonov M, Raijman R and Gorodzeisky A (2008) Foreigners' impact on European societies: public views and perceptions in a cross-national comparative perspective. International Journal of Comparative Sociology 49, 5-29.

Soroka SN (2006) Good news and bad news: asymmetric responses to economic information. The Journal of Politics 68, 372-385.

Thelen KA (1991) Union of Parts: Labor Politics in Postwar Germany. Ithaca and London: Cornell University Press.

Tversky A and Kahneman D (1974) Judgment under uncertainty: heuristics and biases. Science 185, 1124-1131.

Walter S (2010) Globalization and the welfare state: testing the microfoundations of the compensation hypothesis. International Studies Quarterly 54, 403-426.

Weinstein ND (1980) Unrealistic optimism about future life events. Journal of Personality and Social Psychology 39, 806.

Weymouth S (2017) Service firms in the politics of US trade policy. International Studies Quarterly 61, 935-947.

Cite this article: Wu N (2022). Misattributed blame? Attitudes toward globalization in the age of automation. Political Science Research and Methods 10, 470-487. https://doi.org/10.1017/psrm.2021.43 